\title{
Desulfuromonas thiophila sp. nov., a New Obligately Sulfur-Reducing Bacterium from Anoxic Freshwater Sediment
}

\author{
KAI FINSTER, ${ }^{1 *}$ JOHN D. COATES, ${ }^{2}$ WERNER LIESACK, ${ }^{3}$ AND NORBERT PFENNIG ${ }^{4}$ \\ Institute of Biological Sciences, Department of Microbial Ecology, University of Arhus, Ny Munkegade, DK-8000 Arhus \\ C, Denmark'; Water Resources Division, U.S. Geological Survey, Reston, Virginia 22092²; and Max-Planck-Institut \\ für terrestrische Mikrobiologie, D-35043 Marburg, ${ }^{3}$ and Primelweg 12, D-88662 Überlingen, ${ }^{4}$ Germany
}

\begin{abstract}
A mesophilic, acetate-oxidizing, sulfur-reducing bacterium, strain $\mathrm{NZ27}^{\mathrm{T}}$, was isolated from anoxic mud from a freshwater sulfur spring. The cells were ovoid, motile, and gram negative. In addition to acetate, the strain oxidized pyruvate, succinate, and fumarate. Sulfur flower could be replaced by polysulfide as an electron acceptor. Ferric nitrilotriacetic acid was reduced in the presence of pyruvate; however, this reduction did not sustain growth. These phenotypic characteristics suggested that strain $\mathrm{NZ27}^{\mathrm{T}}$ is affiliated with the genus Desulfuromonas. A phylogenetic analysis based on the results of comparative 16S ribosomal DNA sequencing confirmed that strain $\mathrm{NZ27}^{\mathrm{T}}$ belongs to the Desulfuromonas cluster in the recently proposed family "Geobacteraceae" in the delta subgroup of the Proteobacteria. In addition, the results of DNA-DNA hybridization studies confirmed that strain $\mathrm{NZ27}^{\mathrm{T}}$ represents a novel species. Desulfuromonas thiophila, a name tentatively used in previous publications, is the name proposed for strain $\mathrm{NZ27}^{\mathrm{T}}$ in this paper.
\end{abstract}

Bacteria that are able to grow by linking the oxidation of acetate to the reduction of elemental sulfur have been known since Pfennig and Biebl described the isolation of Desulfuromonas acetoxidans in $1976(26)$. While a number of strains of the genus Desulfuromonas have been isolated and deposited in culture collections (33), Desulfuromonas acetoxidans (with type strain DSM 864) is the only species that has been validly published previously (26). Recently, two other species, the freshwater organism "Desulfuromonas acetexigens" (with type strain 2873 [= DSM 1397]) (10) and the marine organism "Desulfuromonas palmitatis" (with type strain SDBY1 [= ATCC 51701]) (4), have been characterized. Data obtained for a second freshwater strain (isolate $\mathrm{NZ27} 7^{\mathbf{T}}$ ), which was tentatively named Desulfuromonas thiophila, have been published in review articles $(31,33)$. However, a valid description of this strain has not been published previously.

In this paper we present a detailed characterization of $D e$ sulfuromonas thiophila $\mathrm{NZ2} 7^{\mathrm{T}}$, including a phenotypic description, the phylogenetic affiliation of this organism with known species of the recently described family "Geobacteraceae" (19), and the results of DNA-DNA hybridization studies performed with closely related species of the genus Desulfuromonas. Based on the genotypic and phenotypic differences between strain NZ27 and the other members of the genus Desulfuromonas, we propose that strain NZ27 is the type strain of a new species, Desulfuromonas thiophila.

\section{MATERIALS AND METHODS}

Source of the organism. Sulfur-reducing strain $N Z 27^{\mathrm{T}}$ was isolated in 1979 by Bache and Pfennig (1) from anoxic mud from a freshwater sulfur spring at Ngawha Springs in Moerewa, New Zealand (North Island).

Media and cultivation conditions. The basal medium used for cultivation of freshwater strain $\mathrm{NZ}_{2} 7^{\mathrm{T}}$ contained (per liter) $0.5 \mathrm{~g}$ of $\mathrm{NaCl}, 0.2 \mathrm{~g}$ of $\mathrm{MgCl}_{2} \cdot 6 \mathrm{H}_{2} \mathrm{O}$, $0.1 \mathrm{~g}$ of $\mathrm{CaCl}_{2} \cdot 2 \mathrm{H}_{2} \mathrm{O}, 0.1 \mathrm{~g}$ of $\mathrm{NH}_{4} \mathrm{Cl}, 0.2 \mathrm{~g}$ of $\mathrm{KH}_{2} \mathrm{PO}_{4}$, and $0.25 \mathrm{~g}$ of KCl. After the medium was autoclaved and cooled under oxygen-free $\mathrm{N}_{2}$, the following additions were made from sterile stock solutions: $30 \mathrm{ml}$ of $1 \mathrm{M} \mathrm{NaHCO}$ per liter, $3 \mathrm{ml}$ of $0.5 \mathrm{M} \mathrm{Na}_{2} \mathrm{~S}$ per liter, $2 \mathrm{ml}$ of trace element solution SL 10a (8) per liter, $1 \mathrm{ml}$ of a vitamin $\mathrm{B}_{12}$ solution per liter, $1 \mathrm{ml}$ of a thiamine solution per liter, and $1 \mathrm{ml}$ of a vitamin mixture per liter (32). After the $\mathrm{NaHCO}_{3}$ was added, the medium was handled under a gas phase containing dinitrogen and $\mathrm{CO}_{2}(90: 10)$.

* Corresponding author. Phone: 45-89-42-3241. Fax: 45-86-12-7191. E-mail: Kai@bio.aau.dk.
Finally, the medium was dispensed into $50-\mathrm{ml}$ screw-cap bottles, leaving a small air bubble in each bottle.

Substrates were added to the basal medium from sterile stock solutions. Sterile suspensions of highly purified elemental sulfur (sulfur flower) and a polysulfide solution were prepared as described by Widdel and Pfennig (33). Elemental sulfur was aseptically added in pea size amounts to $50 \mathrm{ml}$ of medium. Cultures were incubated in the dark at 28 or $30^{\circ} \mathrm{C}$.

Enrichment and isolation. For enrichment cultures, the basal medium in $50-\mathrm{ml}$ screw-cap bottles was supplemented with $5 \mathrm{mM}$ acetate as an electron donor and carbon source and elemental sulfur as an electron acceptor. The bottles were inoculated with $2 \mathrm{ml}$ of anoxic mud, incubated at $28^{\circ} \mathrm{C}$ in the dark, and thoroughly mixed each day. A slight turbidity and a marked increase in sulfide concentration were observed in consecutive passages, and these characteristics indicated that the enrichment cultures were positive. A pure culture was obtained by repeated use of deep agar dilution series (25). Agar deeps (1\% agar) contained basal medium supplemented with elemental sulfur and $2 \mathrm{ml}$ of polysulfide (from a $4 \mathrm{M}$ stock solution) per liter, which resulted in preparations containing highly dispersed elemental sulfur and polysulfide. The solidified agar deeps developed an opaque lemon color. Appearance of pink to red colonies indicated that sulfur reducers of the Desulfuromonas type were present. In addition to microscopic examination, isolates were checked for culture purity in Difco AC medium.

Phenotypic characteristics. Gram staining of strain NZ27 ${ }^{\mathrm{T}}$ was performed by the method of Hucker, and flagellation was determined by the staining method of Leifson as described in the Manual of Methods for General Bacteriology (12) Motility was examined by phase-contrast microscopy.

Substrate tests. Potential electron donors and acceptors were tested in $20-\mathrm{m}$ screw-cap tubes, each of which contained a glass bead to disrupt clumbs of elemental sulfur. Electron donors were tested with elemental sulfur as the electron acceptor. In the electron acceptor tests, pyruvate $(5 \mathrm{mM})$ served as the electron donor. Unless otherwise indicated, the various electron acceptors were added at a concentration of $10 \mathrm{mM}$. Growth was monitored by measuring turbidity for 4 weeks.

Growth parameters. The $\mathrm{pH}$ tolerance, salt tolerance, and temperature tolerance of strain $\mathrm{NZ} 27^{\mathrm{T}}$ were determined by performing growth tests in which the changes in the optical density of the culture medium were monitored spectrophotometrically. Optimum growth was identified by comparing the optical densities of cultures after 3 days of incubation, and the growth range was determined after 28 days. In all of the tests, strain $\mathrm{NZ}^{2} 7^{\mathbf{T}}$ was grown in basal medium supplemented with elemental sulfur and pyruvate. We were careful not to resuspend the sulfur particles prior to the measurements.

To determine the $\mathrm{pH}$ range of strain $\mathrm{NZ}^{2} 7^{\mathrm{T}}$, different amounts of sterile solutions of $\mathrm{HCl}(1 \mathrm{M})$ and $\mathrm{Na}_{2} \mathrm{CO}_{3}(1 \mathrm{M})$ were pipetted into inoculated $50-\mathrm{ml}$ screw-cap bottles, and the contents were thoroughly mixed and transferred into $20-\mathrm{ml}$ screw-cap test tubes. Finally, the $\mathrm{pH}$ of the liquid that remained in each 50 -ml bottle was determined.

The salt tolerance of strain $\mathrm{NZ}_{2} 7^{\mathrm{T}}$ was determined by supplementing $\mathrm{NaCl}$ and $\mathrm{MgCl}_{2}$-free basal medium containing elemental sulfur, pyruvate, and inoculum $(5 \% \mathrm{vol} / \mathrm{vol})$ with different amounts of $\mathrm{NaCl}$ and $\mathrm{MgCl}_{2}$ from sterile stock solutions so that the concentrations desired were obtained. The cultures used for salt and $\mathrm{pH}$ tolerance determinations were incubated at $30^{\circ} \mathrm{C}$ in the dark. The temperature range was determined by incubating inoculated test tubes in an 
insulated temperature gradient block. The lowest temperature tested was $0^{\circ} \mathrm{C}$, and the highest temperature tested was $50^{\circ} \mathrm{C}$.

Analytical procedures. Sulfide was quantified by the methylene blue method described by Cline (3). The presence of cytochromes was determined with whole cells harvested at the late exponential growth phase. Difference spectra were obtained with air-oxidized and dithionite-reduced cell suspensions. The guanineplus-cytosine ratio was determined by the thermal denaturation method (23) and high-performance liquid chromatography (HPLC) separation followed by UV detection (29). Calibration and $\mathrm{G}+\mathrm{C}$ content determinations by the latter method were performed as described by Mesbah et al. (24) at the Deutsche Sammlung von Mikroorganismen und Zellkulturen GmbH (Braunschweig, Germany)

Iron metabolism. Four $100-\mathrm{ml}$ cultures of strain $\mathrm{NZ}_{2} 7^{\mathrm{T}}$ were grown with pyruvate as the electron donor and polysulfide as the electron acceptor. After 5 days, the cells were harvested by centrifugation at $5,000 \times g$ and washed with anoxic bicarbonate buffer ( $2.5 \mathrm{~g} /$ liter; $\mathrm{pH} 7)$ prepared under $\mathrm{N}_{2}-\mathrm{CO}_{2}(80: 20)$ as described previously (21). The cells were resuspended in bicarbonate buffer. The experiment was performed in duplicate in 15 -ml serum vials containing $10 \mathrm{mM}$ pyruvate and $10 \mathrm{mM}$ ferric nitrilotriacetic acid [Fe(III)-NTA]. Fe(III)-NTA (pH 7) was prepared as described previously (27). The amount of $\mathrm{HCl}$-extractable $\mathrm{Fe}(\mathrm{II})$ was determined by the ferrozine assay as described previously (20). Two controls were used; the first control was prepared like the test vials, but the cells were heat killed in an $80^{\circ} \mathrm{C}$ water bath for $5 \mathrm{~min}$, and pyruvate was omitted from the second control. All of the vials were inoculated with $0.1 \mathrm{ml}$ of the cell suspension and incubated at $30^{\circ} \mathrm{C}$.

To test for growth, an inoculum was obtained by transferring strain $\mathrm{NZ}^{\mathrm{T}} \mathrm{T}^{\mathrm{T}}$ from an active polysulfide-reducing culture into basal medium (10\% inoculum) containing $\mathrm{Fe}$ (III)-NTA $(10 \mathrm{mM})$ as the sole electron acceptor and pyruvate as the sole electron donor. When all of the $\mathrm{Fe}$ (III) was reduced (approximately 7 days), this culture was used to inoculate (10\% inoculum) three $100-\mathrm{ml}$ portions of basal medium containing $10 \mathrm{mM}$ Fe(III)-NTA as the sole electron acceptor. Pyruvate $(10 \mathrm{mM})$ was added to two of the vials but not to the third. All of the vials were incubated at $30^{\circ} \mathrm{C}$. Growth was monitored by monitoring $\mathrm{Fe}(\mathrm{II})$ production and determining epifluorescent cell counts by acridine orange staining.

Phylogenetic analysis. DNA isolation, PCR-mediated amplification of the almost complete 16S rRNA gene, and a sequence analysis were performed as described by Liesack and Finster (18). Both strands of the 16S ribosomal DNA (rDNA) PCR product were completely sequenced by using a standard set of oligonucleotide primers (17). The $16 \mathrm{~S}$ rDNA sequence of strain $\mathrm{NZ}^{\mathrm{T}} 7^{\mathrm{T}}$ was manually aligned and compared with reference sequences of various members of the delta subgroup of the Proteobacteria obtained from the EMBL database (6) and the Ribosomal Database Project (22). The phylogenetic position of strain $\mathrm{NZ27}^{\mathrm{T}}$ was deduced by comparing the $16 \mathrm{~S}$ rDNA sequence of this organism with the 16S rDNA sequences of representative members of the recently proposed family "Geobacteraceae" (19). For tree construction we considered only those positions at which bases could be aligned unambiguously $(1,224$ nucleotide positions). Pairwise evolutionary distances were computed by using the correction of Jukes and Cantor (16) implemented in the DNADIST program of the PHYLIP (version 3.5) package (7). A tree on which the phylogenetic relationships were estimated was derived by using the FITCH program of the same package with a random-order input of sequences and the global rearrangement option. The accession numbers for the reference nucleotide sequences used to construct the phylogenetic tree are as follows: Desulfuromonas acetoxidans, M26634; "Desulfuromonas acetexigens," U23140; "Desulfuromonas palmitatis," U28172; Desulfuromusa kysingii, X79414; "Geobacter chapelleii," U41561; "Geobacter hydrogenophilus," U46860; Geobacter metallireducens, L07834; Geobacter sulfurreducens, U13928; Pelobacter acetylenicus, X70955; Pelobacter acidigallici, X77216; Pelobacter carbinolicus, X79419; Pelobacter propionicus, X70964; Pelobacter venetianus, U41562; and Desulfomonile tiedjei, M26635.

DNA-DNA hybridization. DNA-DNA hybridizations were carried out by workers at the Identification Service of the Deutsche Sammlung von Mikroorganismen und Zellkulturen GmbH. Genomic DNAs were isolated by chromatography on hydroxyapatite by using the procedure of Cashion et al. (2). DNA-DNA hybridizations were performed by the spectroscopic method of De Ley et al. (5) with modifications described by Huss et al. (14) by using a spectrophotometer (Gilford System model 2600) equipped with a thermoprogrammer (Gilford model 2527-R) and a plotter. The DNA concentration was $50 \mu \mathrm{g} / \mathrm{ml}$. The optimal temperature of renaturation $\left(70^{\circ} \mathrm{C}\right)$ was calculated from the average $\mathrm{G}+\mathrm{C}$ content of the samples by the formula of Gillis et al. (13). The DNA reassociation rate was calculated by performing a regression analysis between 10 and $30 \mathrm{~min}$ after start of the reaction by using the computer program TRANSFER.BAS (15). The homology values were calculated by using the formula of De Ley et al. (5). Each measurement was made three times.

Chemicals. All of the chemicals were reagent grade and were obtained from commercial suppliers.

Nucleotide sequence accession number. The $16 \mathrm{~S}$ rDNA sequence of strain $\mathrm{NZ} 27^{\mathrm{T}}$ has been deposited in the EMBL, GenBank, and DDBJ nucleotide sequence databases under accession no. Y11560.

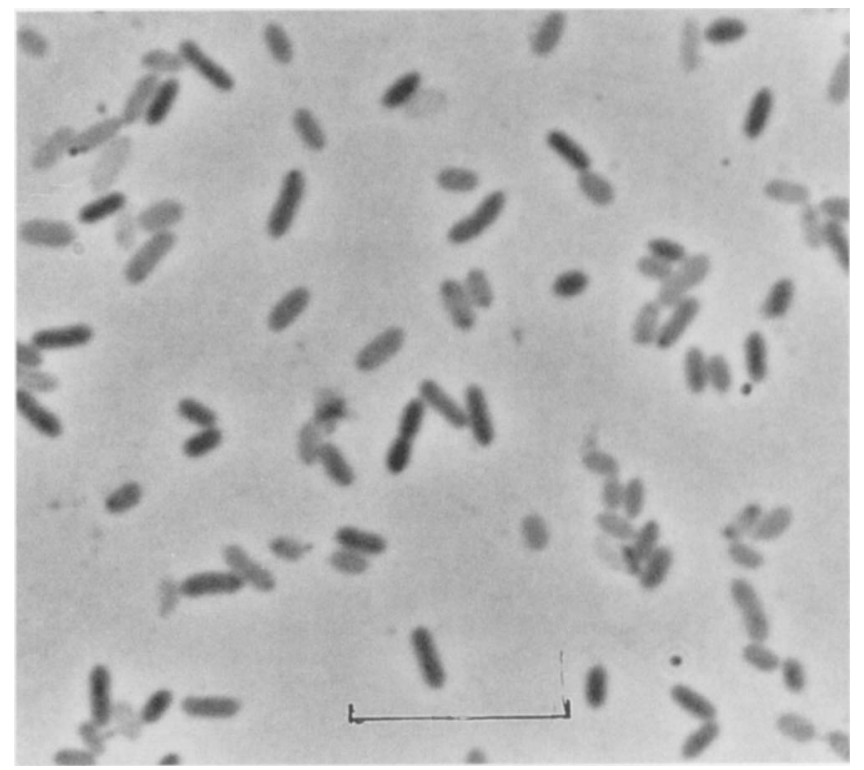

FIG. 1. Phase-contrast photomicrograph of Desulfuromonas thiophila NZ27 $^{\mathrm{T}}$ grown with pyruvate and polysulfide. Bar $=10 \mu \mathrm{m}$.

\section{RESULTS}

Enrichment and isolation. Enrichment cultures for sulfurreducing bacteria were prepared with medium containing acetate $(5 \mathrm{mM})$ and sulfur flower. Anoxic mud from Ngawha Sulfur Springs near Moerewa, New Zealand, was used as the inoculum. The incubation temperature was $28^{\circ} \mathrm{C}$. Positive enrichment cultures were obtained after 2 weeks. These enrichment cultures were transferred every week. After four consecutive transfers, a subsample was used to inoculate deep agar dilution series. A few well-separated colonies were isolated from the third dilution series and transferred to liquid culture media supplemented with acetate $(5 \mathrm{mM})$ and polysulfide. One of the cultures, strain $\mathrm{NZ27}{ }^{\mathrm{T}}$, was maintained as a stock culture and was used for further studies.

Phenotypic characteristics. (i) Morphology. Cells of strain $\mathrm{NZ27}^{\mathrm{T}}$ were ovoid rods that were 0.7 to $0.8 \mu \mathrm{m}$ wide and 1.5 to $2 \mu \mathrm{m}$ long (Fig. 1) and motile. Flagellar staining revealed the presence of one polar flagellum. The cells stained gram negative. In agar medium smooth pink to red colonies were formed.

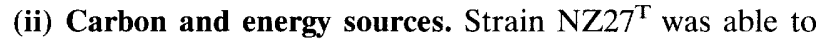
grow with acetate, pyruvate, succinate, and fumarate in the presence of elemental sulfur. The following chemicals were tested but were not used by strain $N Z 27^{\mathrm{T}}$ for growth when elemental sulfur was added as the electron acceptor (the concentration of the electron donor was $5 \mathrm{mM}$ unless indicated otherwise): $\mathrm{H}_{2}$, formate $(10 \mathrm{mM})$, propionate, butyrate, caproate, oenanthate, palmitate $(2 \mathrm{mM})$, mystrinate $(2 \mathrm{mM})$, lactate, cyclohexanecarboxylate, citrate, malate, tartrate, malonate, glucose, fructose, mannitol, glycerol, glycolate, methanol, ethanol, $n$-propanol, butanol, benzoate $(1 \mathrm{mM})$, betaine, alanine, aspartate, glutamate, Casamino Acids (0.1\%), yeast extract $(0.1 \%)$, and peptone $(0.1 \%)$. A fermentative type of metabolism with fumarate, malate, or sugars was not observed. Elemental sulfur was the only electron acceptor with which sustained growth occurred. Fe(III)-NTA (10 mM) was reduced; however, this transformation was not coupled with growth (Fig. 2). Sulfate, sulfite, thiosulfate, nitrate, fumarate, 


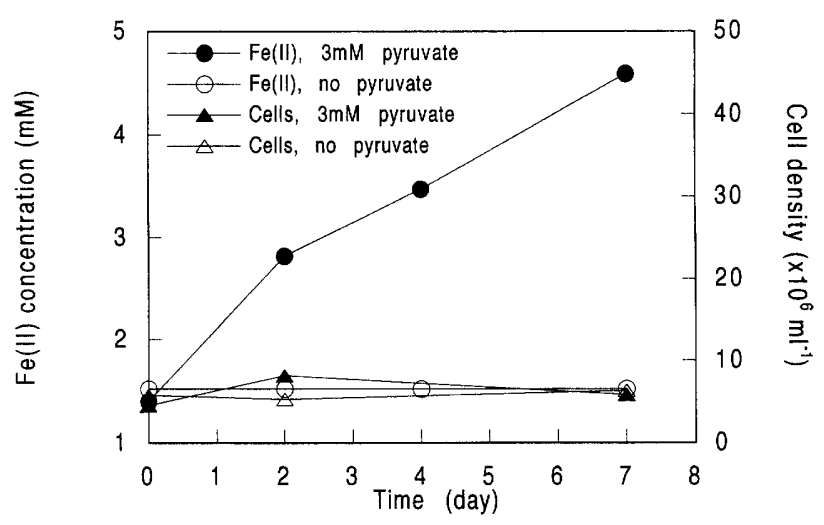

FIG. 2. Fe(II) concentrations $(\boldsymbol{\bullet}$ and $O)$ and cell densities $(\boldsymbol{\Delta}$ and $\Delta)$ as a function of time. $\mathrm{Fe}$ (III)-NTA was used as the electron acceptor, and pyruvate was used as the electron donor. Pyruvate-free preparations were used as controls.

malate, dimethyl sulfoxide, and trimethylamine- $N$-oxide dihydrate were not utilized as electron acceptors.

(iii) Growth factor requirements and salt tolerance. The complex vitamin solution which was originally used during enrichment and isolation of strain $\mathrm{NZ2} 27^{\mathrm{T}}$ could be replaced by biotin. Biotin was essential for growth; however, the threshold concentration necessary for growth was not determined. Amino acids were not required.

Strain NZ27 ${ }^{\mathrm{T}}$ grew equally well in the presence of 0 to $0.3 \%$ $\mathrm{NaCl}$ and in the presence of 0.03 to $0.12 \% \mathrm{MgCl}_{2} \cdot 6 \mathrm{H}_{2} \mathrm{O}$. Growth was inhibited by $\mathrm{NaCl}$ concentrations greater than $1.2 \%$ and by $\mathrm{MgCl}_{2} \cdot 6 \mathrm{H}_{2} \mathrm{O}$ concentrations greater than $0.35 \%$.

(iv) $\mathbf{p H}$ and temperature range. Strain $\mathrm{NZ2} 7^{\mathrm{T}}$ grew at $\mathrm{pH}$ 6.5 to 8.2 , and optimum growth occurred at $\mathrm{pH} 6.9$ to 7.9 . The minimum growth temperature was $10^{\circ} \mathrm{C}$, and the maximum temperature was $39^{\circ} \mathrm{C}$. After growth at $39^{\circ} \mathrm{C}$, the cells were generally larger than cells grown at lower temperatures, and a large number of spheroplasts were observed after 1 week of incubation. After transfer to fresh medium and incubation at lower temperatures, cells having the original morphology developed. The optimum growth temperature was between 26 and $30^{\circ} \mathrm{C}$. No growth occurred at temperatures above $40^{\circ} \mathrm{C}$.

(v) Pigments. The difference spectra of whole cells had maxima at 419, 523, and $553 \mathrm{~nm}$. These absorption maxima are characteristic of type $c$ cytochromes.

Genotypic characteristics. (i) DNA-DNA hybridization. DNA-DNA hybridization experiments were performed with strain NZ27 $7^{\mathrm{T}}$, Desulfuromonas acetoxidans DSM 684" "Desulfuromonas acetexigens" DSM 1397, and "Desulfuromonas palmitatis" ATCC $51701^{\mathrm{T}}$. The levels of DNA-DNA hybridization with strain $\mathrm{NZ}_{27}^{\mathrm{T}}$ were between 22 and $31 \%$ (Table 1). These values indicated that the strains tested belong to different species (30).

(ii) DNA base composition. The $\mathrm{G}+\mathrm{C}$ content of the DNA of strain $\mathrm{NZ}_{2} 7^{\mathrm{T}}$ was $61 \mathrm{~mol} \%$, as determined by the thermal denaturation method. The same ratio was obtained by HPLC. The values previously reported for "Desulfuromonas acetexigens" (10) were also confirmed by the HPLC technique, while the value for Desulfuromonas acetoxidans was slightly different (Table 1).

Phylogenetic position. The comparative analysis of the almost complete 16S rDNA sequence confirmed that strain $\mathrm{NZ27}{ }^{\mathrm{T}}$ belongs to the Desulfuromonas cluster of the recently proposed family "Geobacteraceae" (19). The most closely related species was Desulfuromonas acetoxidans (level of similarity, 96.6\%) (Fig. 3), as reported previously on the basis of the results of comparative $16 \mathrm{~S}$ rRNA oligonucleotide cataloging studies (11). The levels of similarity between the 16S rDNA sequence of strain NZ27 $7^{\mathrm{T}}$ and the $16 \mathrm{~S}$ rDNA sequences of "Desulfuromonas acetexigens" and "Desulfuromonas palmitatis" were 95.0 and $94.4 \%$, respectively. The levels of similarity with $P$. venetianus, $P$. carbinolicus, and $P$. acetylenicus were 95.4 , 94.8 , and $94.4 \%$, respectively, while the levels of similarity with members of the genus Geobacter were $93.1 \%$ or less. A bootstrap analysis based on 1,000 resamplings to test the statistical significance of the interior branches confirmed that the lineage formed by strain NZ27 ${ }^{\mathrm{T}}$ and Desulfuromonas acetoxidans was distinct, with a bootstrap value of 100 (expressed as a percentage of outcome). The general topology of the tree constructed in this study (Fig. 3) is almost identical to the topology of the tree published by Lonergan et al. (19); there are only slight differences in the interior branch points within the Desulfuromonas cluster.

\section{DISCUSSION}

In this paper we describe the isolation and identification of a mesophilic, obligately anaerobic, sulfur-reducing bacterium (strain NZ27 $7^{\mathrm{T}}$ ) obtained from the anoxic sediment of a freshwater sulfur spring. The results of a previous study of the phylogenetic affiliation of this isolate with other sulfur-reducing bacteria indicated that strain NZ2 $7^{\mathrm{T}}$ is most closely related to Desulfuromonas acetoxidans and "Desulfuromonas acetexigens," with $S_{\mathrm{AB}}$ values of 0.64 and 0.59 , respectively (11). The results of the comparative analysis of the almost complete $16 \mathrm{~S}$ rDNA sequences confirmed the previous finding that strain $\mathrm{NZ2} 7^{\mathrm{T}}$ and Desulfuromonas acetoxidans form a distinct line of descent. DNA-DNA hybridization studies of strain $\mathrm{NZ}^{\mathrm{T}} 7^{\mathrm{T}}$ and the previously described species of the genus Desulfuromonas, including Desulfuromonas acetoxidans, gave reassociation values that were not greater than $31 \%$ (Table 1). These values were far below the DNA-DNA reassociation value of about $70 \%$ which is used to separate related organisms into different

TABLE 1. G+C contents of DNAs as determined by the thermal denaturation method and HPLC and DNA-DNA hybridization results

\begin{tabular}{|c|c|c|c|c|c|}
\hline \multirow[b]{2}{*}{ Strain } & \multicolumn{2}{|c|}{$\mathrm{G}+\mathrm{C}$ content $(\mathrm{mol} \%)$} & \multicolumn{3}{|c|}{$\%$ Similarity to: } \\
\hline & $\begin{array}{c}\text { Thermal } \\
\text { denaturation } \\
\text { method }\end{array}$ & HPLC & $\begin{array}{l}\text { Desulfuromonas acetoxidans } \\
\text { DSM } 684^{\mathrm{T}}\end{array}$ & $\begin{array}{c}\text { "Desulfuromonas acetexigens" } \\
\text { DSM } 1397^{\mathrm{T}}\end{array}$ & $\begin{array}{l}\text { "Desulfuromonas palmitatis" } \\
\text { ATCC } 51701^{\mathrm{T}}\end{array}$ \\
\hline Desulfuromonas acetoxidans DSM $684^{\mathrm{T}}$ & $51 \pm 1$ & $53.6 \pm 0.4$ & & & \\
\hline "Desulfuromonas acetexigens" DSM $1397^{\mathrm{T}}$ & $62 \pm 1$ & $62.3 \pm 0.4$ & 20 & & \\
\hline "Desulfuromonas palmitatis" ATCC $51701^{\mathrm{T}}$ & ND & $54.7 \pm 0.2$ & 22 & 37 & \\
\hline $\mathrm{NZ}_{27}^{\mathrm{T}}\left(=\operatorname{DSM} 8987^{\mathrm{T}}\right)$ & $61 \pm 1$ & $61.6 \pm 0.2$ & 27 & 22 & 31 \\
\hline
\end{tabular}

\footnotetext{
${ }^{a} \mathrm{ND}$, not determined.
} 


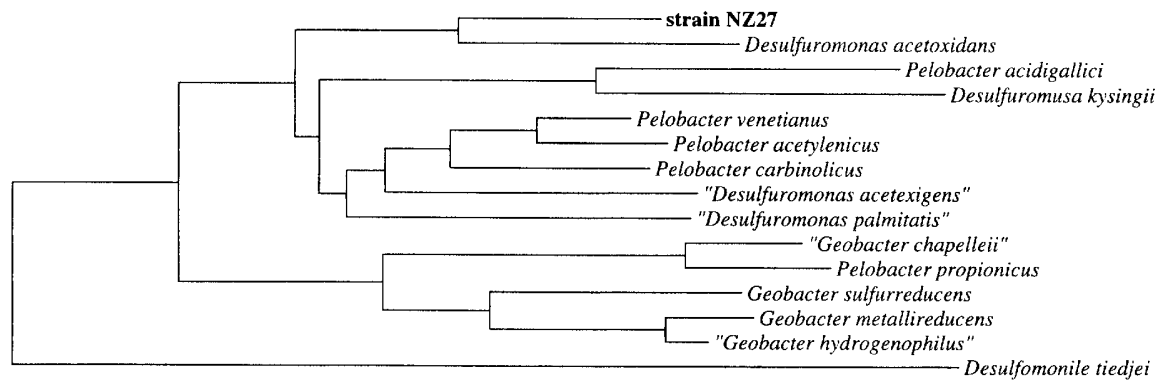

$2 \%$

FIG. 3. Phylogenetic tree constructed for strain NZ27 ${ }^{\mathrm{T}}$ and 13 reference organisms belonging to the family "Geobacteraceae" of the delta subgroup of the Proteobacteria. The 16S rDNA sequence of Desulfomonile tiedjei was used as an outgroup sequence. Scale bar $=2 \%$ difference in nucleotide sequences as determined by measuring the horizontal branch lengths connecting two species.

species (30). Thus, these results suggest that strain $\mathrm{NZ}_{2} 7^{\mathrm{T}}$ is a new species of the genus Desulfuromonas. The relationship between the overall similarity of the $16 \mathrm{~S}$ rDNA sequences and the DNA-DNA reassociation values obtained for strain $\mathrm{NZ}_{2} 7^{\mathrm{T}}$ and the other members of the genus Desulfuromonas confirmed the general finding that strains with levels of $16 \mathrm{~S}$ rDNA similarity below the threshold value of $97 \%$ never exhibit DNA-DNA reassociation values of $70 \%$ or more (28).

Strain $N Z 27^{\mathrm{T}}$ and all previously described members of the genus Desulfuromonas have the ability to oxidize acetate with concomitant reduction of elemental sulfur to hydrogen sulfide (33). This characteristic has also been found in members of the recently described genera Desulfurella and Desulfuromusa (1a, $9,18)$. In contrast to all of the other members of the family "Geobacteraceae" tested for the ability to grow by reducing iron (19), strain $\mathrm{NZ}^{2} 7^{\mathrm{T}}$ was not able to grow by reducing this element, but used only elemental sulfur as an electron acceptor. However, it is able to reduce Fe(III)-NTA.

Like type strain Desulfuromonas acetoxidans DSMZ 684 cells, cells of strain NZ27 $7^{\mathrm{T}}$ are ovoid to rod shaped and motile and form smooth pink to red colonies in agar medium. They also require biotin for growth. Like the other members of the Desulfuromonas cluster, strain $\mathrm{NZ}^{2} 7^{\mathrm{T}}$ contains type $c$ cytochromes.

Based on the results of the polyphasic approach described above, we propose the new species Desulfuromonas thiophila for strain $\mathrm{NZ2} 7^{\mathrm{T}}$.

Description of Desulfuromonas thiophila sp. nov. Desulfuromonas thiophila (thi.o.phi'la. Gr. n. thios, sulfur; Gr. adj. philos, loving; M.L. fem. adj. thiophila sulfur loving). Cells are ovoid, 0.7 to $0.8 \mu \mathrm{m}$ wide by 1.5 to $2.0 \mu \mathrm{m}$ long. Multiplication is by binary fission. Cells are motile by means of polar flagella. Obligately anaerobic. Chemotrophic growth occurs in mineral medium supplemented with 0.01 to $0.03 \% \mathrm{Na}_{2} \mathrm{~S} \cdot 9 \mathrm{H}_{2} \mathrm{O}$ as a reductant. Growth is inhibited by $\mathrm{NaCl}$ concentrations greater than $1.2 \%$. Biotin is required as a growth factor. Acetate, pyruvate, succinate, and fumarate are used as electron donors and carbon sources in the presence of $30 \mathrm{mM}$ hydrogen carbonate. Elemental sulfur is as the only electron acceptor utilized for growth. Fe(III)-NTA is reduced with pyruvate; this reduction does not sustain growth. The $\mathrm{pH}$ range is 6.5 to 8.2 ; the optimum $\mathrm{pH}$ is 6.9 to 7.9 . The optimum growth temperature is 26 to $30^{\circ} \mathrm{C}$.

Accumulations of cells in colonies or pellets are pink to reddish; under reducing conditions cell suspensions exhibit absorption spectra characteristic of type $c$ cytochromes (absorption maxima at 419,523 , and $553 \mathrm{~nm}$ ).
The $\mathrm{G}+\mathrm{C}$ content of the genomic DNA of strain $\mathrm{NZ}^{\mathrm{T}} 7^{\mathrm{T}}$ is $61.0 \pm 1 \mathrm{~mol} \%$ as determined by the thermal denaturation method and $61.6 \pm 0.2 \mathrm{~mol} \%$ as determined by HPLC.

Phylogenetically, strain NZ27 ${ }^{\mathrm{T}}$ belongs to the Desulfuromonas cluster of the recently proposed family "Geobacteraceae" in the delta subgroup of the Proteobacteria and is most closely related to Desulfuromonas acetoxidans.

The habitat is anoxic mud of a freshwater sulfur spring.

The type strain was isolated from anoxic mud from a freshwater sulfur spring at Ngawha Springs near Moerewa, New Zealand.

The type strain is strain NZ27, which has been deposited in the Deutsche Sammlung von Mikroorganismen und Zellkulturen, Braunschweig, Germany, as strain DSMZ 8987.

\section{ACKNOWLEDGMENTS}

K.F. is indebted to Niels Peter Revsbech for support. Sonja Fleissner is acknowledged for technical assistance.

This project was financed by a European Union project on Coastal Lagoon Eutrophication and Anaerobic Processes (CLEAN) (contract EV5V-CT92-008) and by the Danish Committee on Biotechnology. J.D.C. was supported by the U.S. Geological Survey National Research Program

\section{REFERENCES}

1. Bache, R., and N. Pfennig. Unpublished data.

1a.Bonch-Osmolovskaya, E. A., T. G. Solokova, N. A. Kostrikina, and G. A Zavarzin. 1990. Desulfurella acetivorans gen. nov. and sp. nov., a new thermophilic sulfur-reducing eubacterium. Arch. Microbiol. 153:151-155.

2. Cashion, P., M. A. Holder-Franklin, J. McCully, and M. Franklin. 1977. A rapid method for the base ratio determination of bacterial DNA. Anal. Biochem. 81:461-466.

3. Cline, J. D. 1969. Spectrophotometric determination of hydrogen sulfide in natural waters. Limnol. Oceanogr. 14:454-458.

4. Coates, J. D., D. J. Lonegran, E. J. P. Philips, H. Jenter, and D. Lovley. 1995. Desulfuromonas palmitatis sp. nov., a marine dissimilatory $\mathrm{Fe}$ (III) reducer that can oxidize long-chain fatty acids. Arch. Microbiol. 164:406-413.

5. De Ley, J., H. Cattoir, and A. Reynaerts. 1970. The quantitative measurement of DNA hybridization from renaturation rates. Eur. J. Biochem. 12: 133-142.

6. Emmert, D. B., P. J. Stoehr, G. Stoessner, and G. N. Cameron. 1994. The European Bioinformatics Institute (EBI databases). Nucleic Acids Res. 22: 3445-3449.

7. Felsenstein, J. 1993. PHYLIP (phylogeny inference package), version 3.5c. Department of Genetics, University of Washington, Seattle.

8. Finster, K., Y. Tanimoto, and F. Bak. 1992. Fermentation of methanethiol and dimethylsulfide by a newly isolated methanogenic bacterium. Arch. Microbiol. 157:425-430.

9. Finster, K., and F. Bak. 1993. Complete oxidation of propionate, valerate, succinate, and other organic compounds by newly isolated types of marine, anaerobic, mesophilic, gram-negative, sulfur-reducing eubacteria. Appl. Environ. Microbiol. 59:1452-1460.

10. Finster, K., F. Bak, and N. Pfennig. 1994. Desulfuromonas acetexigens sp. 
nov., a dissimilatory sulfur-reducing eubacterium from anoxic freshwater sediments. Arch. Microbiol. 161:328-332.

11. Fowler, V. J., F. Widdel, N. Pfennig, C. R. Woese, and E. Stackebrandt. 1986 Phylogenetic relationship of sulfate- and sulfur-reducing eubacteria. Syst. Appl. Microbiol. 8:32-41.

12. Gerhardt, P., R. G. E. Murray, R. N. Costilow, E. W. Nester, W. A. Wood, N. R. Krieg, and G. B. Phillips (ed.). 1981. Manual of methods for general bacteriology. American Society for Microbiology, Washington, D.C.

13. Gillis, M., J. De Ley, and M. De Cleene. 1970. The determination of molecular weight of bacterial genome DNA from renaturation rates. Eur. J. Biochem. 12:143-153.

14. Huss, V. A. R., H. Festl, and K. H. Schleifer. 1983. Studies on the spectrophotometric determination of DNA hybridization from renaturation rates. Syst. Appl. Microbiol. 4:184-192.

15. Jahnke, K.-D. 1992. BASIC computer program for evaluation of spectroscopic DNA renaturation data from GILFORD SYSTEM 2600 spectrophotometer on PC/XT/AT type personal computer. J. Microbiol. Methods 15: $61-73$.

16. Jukes, T. H., and C. R. Cantor. 1969. Evolution of protein molecules, p. 21-132. In H. N. Munro (ed.), Mammalian protein metabolism, vol. 3 Academic Press, New York, N.Y.

17. Lane, D. J. 1991. 16S/23S rRNA sequencing, p. 115-175. In E. Stackebrandt and M. Goodfellow (ed.), Nucleic acid techniques in bacterial systematics. John Wiley \& Sons, Inc., New York, N.Y.

18. Liesack, W., and K. Finster. 1994. Phylogenetic analysis of five strains of gram-negative, obligate anaerobic, sulfur-reducing bacteria and the description of Desulfuromusa gen. nov., including Desulfuromusa kysingii sp. nov. Desulfuromusa bakii sp. nov., and Desulfuromusa succinoxidans sp. nov. Int. J. Syst. Bacteriol. 44:753-758.

19. Lonergan, D. J., H. L. Jenter, J. D. Coates, E. J. P. Phillips, T. M. Schmidt and D. R. Lovley, 1996. Phylogenetic analysis of dissimilatory Fe(III)-reducing bacteria. J. Bacteriol. 178:2402-2408.

20. Lovley, D. R., and E. J. P. Philipps. 1987. Rapid assay for microbially reducible ferric iron in aquatic sediments. Appl. Environ. Microbiol. 53: $1536-1540$.

21. Lovley, D. R., S. J. Giovannoni, D. C. White, J. E. Champine, E. J. P. Phillips, A. Gorby, and S. Goodwin. 1993. Geobacter metallireducens gen. nov. sp. nov., a microorganism capable of coupling the complete oxidation of organic compounds to the reduction of iron and other metals. Arch. Microbiol. 159:336-344.
22. Maidak, B. L., N. Larsen, M. J. McCaughey, R. Overbeek, G. J. Olsen, K. Fogel, J. Blandy, and C. R. Woese. 1994. The Ribosomal Database Project. Nucleic Acids Res. 22:3485-3487.

23. Marmur, J., and P. Doty. 1962. Determination of the base composition of deoxyribonucleic acid from its thermal denaturation temperature. J. Mol. Biol. 5:109-118.

24. Mesbah, M., U. Premachandran, and W. B. Whitman. 1989. Precise measurement of the $\mathrm{G}+\mathrm{C}$ content of deoxyribonucleic acid by high-performance liquid chromatography. Int. J. Syst. Bacteriol. 39:159-167.

25. Pfennig, N. 1978. Rhodocyclus purpureus gen. nov. and sp. nov., a ring shaped, vitamin $\mathrm{B}_{12}$-requiring member of the family Rhodospirillaceae. Int. J. Syst. Bacteriol. 28:283-288.

26. Pfennig, N., and H. Biebl. 1976. Desulfuromonas acetoxidans gen. nov. and sp. nov., a new anaerobic, sulfur-reducing, acetate-oxidizing bacterium. Arch. Microbiol. 110:3-12.

27. Roden, E. E., and D. R. Lovley. 1993. Dissimilatory Fe(III) reduction by the marine microorganism Desulfuromonas acetoxidans. Appl. Environ. Microbiol. 59:734-742.

28. Stackebrandt, E., and B. M. Goebel. 1994. Taxonomic note: a place for DNA-DNA reassociation and $16 \mathrm{~S}$ rRNA sequence analysis in the present species definition in bacteriology. Int. J. Syst. Bacteriol. 44:846-849.

29. Tamaoka, J., and K. Komagato. 1984. Determination of DNA base composition by reverse-phase high-performance liquid chromatography. FEMS Microbiol. Lett. 25:125-128.

30. Wayne, L. G., D. J. Brenner, R. R. Colwell, P. A. D. Grimont, O. Kandler, M. I. Krichevsky, L. H. Moore, W. E. C. Moore, R. G. E. Murray, E Stackebrandt, M. P. Starr, and H. G. Trüper. 1987. Report of the Ad Hoc Committee on Reconciliation of Approaches to Bacterial Systematics. Int. J. Syst. Bacteriol. 37:463-464.

31. Widdel, F. 1988. Microbiology and ecology of sulfate- and sulfur-reducing bacteria, p. 469-585. In A. J. B. Zehnder (ed.), Biology of anaerobic microorganisms. John Wiley \& Sons, Inc., New York, N.Y.

32. Widdel, F., and F. Bak. 1992. Gram-negative mesophilic sulfate-reducing bacteria, p. 3352-3378. In A. Balows, H. G. Trüper, M. Dworkin, W. Harder, and K. H. Schleifer (ed.), The prokaryotes, 2nd ed., vol. 4. Springer, New York, N.Y.

33. Widdel, F., and N. Pfennig. 1992. The genus Desulfuromonas and other Gram-negative sulfur-reducing eubacteria, p. 3379-3389. In A. Balows, H. G. Trüper, M. Dworkin, W. Harder, and K. H. Schleifer (ed.), The prokaryotes, 2nd ed., vol. 4. Springer, New York, N.Y. 